\title{
Very low concentration of cerium dioxide nanoparticles induce DNA damage, but no loss of vitality, in human spermatozoa
}

\author{
L. Préaubert ${ }^{\mathrm{a}}$, V. Tassistro ${ }^{\mathrm{a}}$, M. Auffan ${ }^{\mathrm{b}}$, I. Sari-Minodier ${ }^{\mathrm{a}}$, J. Rose ${ }^{\mathrm{b}}$, B. Courbiere ${ }^{\mathrm{a}, \mathrm{c}}$, J. Perrin $^{\mathrm{a}, \mathrm{c}, *}$ \\ a Aix Marseille Univ, CNRS, IRD, Avignon Univ, IMBE UMR 7263, 13397 Marseille, France \\ ${ }^{\mathrm{b}}$ CNRS, Aix Marseille Univ, IRD, CEREGE UM34, UMR 7330, 13545 Aix en Provence, France \\ ${ }^{c}$ Centre Clinico-Biologique d'Assistance Médicale à la Procréation - CECOS, Pôle Femmes Parents Enfants, AP-HM La Conception, Marseille, Cedex 05, France
}

\section{A R T I C L E I N F O}

\section{Keywords:}

Cerium dioxide nanoparticles

Human spermatozoa

DNA damage

Comet assay

Environment

\begin{abstract}
A B S T R A C T
Cerium dioxide nanoparticles $\left(\mathrm{CeO}_{2} \mathrm{NP}\right)$ are widely used for industrial purposes, as in diesel, paint, wood stain and as potential therapeutic applications. The Organization for Economic Cooperation and Development included $\mathrm{CeO}_{2} \mathrm{NP}$ in the priority list of nanomaterials requiring urgent evaluation. As metal nanoparticles can cross the blood-testis barrier, $\mathrm{CeO}_{2} \mathrm{NP}$ could interact with spermatozoa. The genotoxicity of $\mathrm{CeO}_{2} \mathrm{NP}$ was demonstrated in vitro on human cell lines and mouse gametes. However, the effects of $\mathrm{CeO}_{2} \mathrm{NP}$ on human spermatozoa DNA remain unknown. We showed significant DNA damage induced in vitro by $\mathrm{CeO}_{2} \mathrm{NP}$ on human spermatozoa using Comet assay. The genotoxicity was inversely proportional to the concentration $\left(0.01\right.$ to $\left.10 \mathrm{mg} \cdot \mathrm{L}^{-1}\right)$. TEM showed no internalization of $\mathrm{CeO}_{2} \mathrm{NP}$ into the spermatozoa. This study shows for the first time that in vitro exposure to very low concentrations of cerium dioxide nanoparticles can induce significant DNA damage in human spermatozoa. These results add new and important insights regarding the reproductive toxicity of priority nanomaterials, which require urgent evaluation.
\end{abstract}

\section{Introduction}

Due to the extensive industrial production of nanoparticles, human exposure has been increasing exponentially. The reproductive toxicity of nanoparticles is a particularly important issue (Ema et al., 2010; Greco et al., 2015a), as toxic effects can be transgenerational. Indeed, Yoisungnern et al. showed that silver nanoparticles could be internalized into mouse sperm in vitro and subsequently alter fertilization and compromise embryo development (Yoisungnern et al., 2015). Moretti et al. incubated human sperm with high-concentration suspensions of silver and gold nanoparticles in vitro, observed a significant dose-dependent decrease of motility and viability, and described the internalization of Au-NP in sperm cells (Moretti et al., 2013). Taylor et al. recently emphasized the need for a better understanding of the reproductive toxicity of nanoparticles (Taylor et al., 2015).

Cerium dioxide nanoparticles $\left(\mathrm{CeO}_{2} \mathrm{NP}\right)$ are commonly used for industrial purposes, including as a diesel additive (Cassee et al., 2011; Park et al., 2008) or wood stain, and have potential medical applications such as protection against radiation-induced damage (Giri et al., 2013; Sack et al., 2014; Tarnuzzer et al., 2005). $\mathrm{CeO}_{2} \mathrm{NP}$ are on the priority list of nanomaterials requiring urgent evaluation as declared by the Organization for Economic Cooperation and Development (OECD's guidelines, 2011). Indeed, the toxicity/safety assessment of $\mathrm{CeO}_{2} \mathrm{NP}$ is still incomplete, with only a few studies available. It has been shown in rats that $\mathrm{CeO}_{2} \mathrm{NP}$ can cross the blood-testis barrier and accumulate into the testis after in vivo exposure (Geraets et al., 2012); $\mathrm{CeO}_{2} \mathrm{NP}$ could then interact with spermatozoa. The impact of oral administration of citrate-coated 2-5-nm $\mathrm{CeO}_{2} \mathrm{NP}$ on semen parameters was recently investigated in aged rats in vivo (Kobyliak et al., 2015), and an improvement in sperm concentration, motility and morphology was observed in treated rats compared to control rats. Similarly, Falchi et al. reported no intracellular uptake and no impairment of the functional and morphological characteristics of ram sperm after in vitro exposure to high concentrations of $\mathrm{CeO}_{2} \mathrm{NP}$ (Falchi et al., 2016). Conversely, the genotoxicity of $\mathrm{CeO}_{2} \mathrm{NP}$ has been shown in human cell lines, mouse oocytes and spermatozoa (Benameur et al., 2015; Courbiere et al., 2013; Mittal and Pandey, 2014; Preaubert et al., 2015) after in vitro exposure. However, the effects of $\mathrm{CeO}_{2} \mathrm{NP}$ on human sperm DNA remain unknown. Our objective was to study the in vitro genotoxicity of well-characterized $\mathrm{CeO}_{2} \mathrm{NP}$ on human spermatozoa at low doses.

\footnotetext{
* Corresponding author at: Laboratoire Biogénotoxicologie, sous sol aile rouge, Faculté de Médecine, Aix-Marseille Université, 27 bd Jean Moulin, 13005 Marseille, France.

E-mail address: jeanne.perrin@imbe.fr (J. Perrin).
} 


\section{Materials and methods}

\subsection{Physico-chemical characterization of $\mathrm{CeO}_{2}$ nanoparticles}

As the characterization of nanomaterial is of utmost importance for in vitro testing of toxicity (Love et al., 2012), we performed a thorough physico-chemical characterization of the cerium dioxide nanoparticles. $\mathrm{CeO}_{2} \mathrm{NP}$ (Rhodia chemicals) were synthesized by aqueous precipitation of $\mathrm{Ce}^{4+}\left(\mathrm{NO}_{3}{ }^{-}\right)_{4}$ salt at an acidic $\mathrm{pH}$ (Spalla and Cabane, 1993). They are ellipsoidal crystallites with a mean diameter of $\sim 7 \mathrm{~nm}$ and a specific surface area evaluated at $400 \mathrm{~m}^{2} / \mathrm{g}$ (Spalla and Cabane, 1993; Thill et al., 2006). Their hydrodynamic diameters were measured either in a stock suspension using dynamic light scattering (DLS) (NanoZS, Malvern Instruments ${ }^{\circledast}$ Inc., UK) with an optimal measurement range of 1 to $1000 \mathrm{~nm}$ or in FertiCult ${ }^{\circledR}$ medium using laser diffraction (Malvern3000, Malvern Instruments ${ }^{\circledast}$ Inc., UK).

The local atomic environment and oxidation states before and after incubation in FertiCult ${ }^{\circledR}$ were assessed by X-ray absorption spectro-

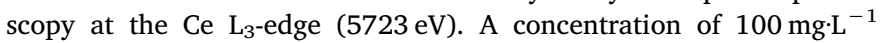
$\mathrm{CeO}_{2} \mathrm{NP}$ were incubated for $1 \mathrm{~h}$ in abiotic FertiCult ${ }^{\circledR}$ medium and then ultracentrifuged at $200,000 \mathrm{~g}$ for $1 \mathrm{~h}$. The solid phase was freeze-dried and analyzed by XAS (CRG-FAME beamline at the ESRF, France). Samples were diluted in BN, pressed into thin pellets, and analyzed at liquid helium temperatures in fluorescence mode with a 30-element solid-state Ge detector. The spectra were compiled from the merge of three scans. XANES (X-ray absorption near edge structure) data were obtained after performing standard procedures for pre-edge subtraction and normalization.

The dissolution of $\mathrm{CeO}_{2} \mathrm{NP}$ after a 1-h incubation in FertiCult ${ }^{\circledR}$ medium was assessed by inductively coupled plasma mass spectrometry (ICP-MS) (PerkinElmer, Nexion $300 \times$ ). The contaminated media (e.g., $0.01 \mathrm{mg} \cdot \mathrm{L}^{-1}$ to $10 \mathrm{mg} \cdot \mathrm{L}^{-1}$ of $\mathrm{CeO}_{2}$ ) were ultracentrifuged at $200,000 \mathrm{~g}$ for $1 \mathrm{~h}$ and the cerium levels were detected in the supernatant.

\subsection{Experimental design}

According to the Organization for Economic Co-operation and Development guideline (OECD, 2014; Lovell and Omori, 2008; Wiklund and Agurell, 2003), we performed 3 independent in vitro experiments and analyzed 3 replicate slides from each experiment.

\subsection{Culture media and reagents}

We used FertiCult IVF $^{\circledR}$ culture medium (FertiPro, Beernem, Belgium), which is specifically designed for in vitro human sperm and embryo culture. All other reagents were provided by Sigma-Aldrich ${ }^{\circledR}$ (St-Quentin-Fallavier, France) unless otherwise mentioned.

\subsection{Collection and in vitro exposure of human spermatozoa}

We used frozen human spermatozoa from 3 healthy fertile donors. The semen samples had been diluted in cryoprotectant medium according to the manufacturer's instructions (Spermfreeze; JCD, La Mulatiere, France), transferred to high security straws with a capacity of $300 \mu \mathrm{L}$ (Cryo Bio System, L'Aigle, France), and then stored in liquid nitrogen until further use. These spermatozoa were purchased from GERMETHEQUE biobank, which obtained informed consent from each donor for inclusion of samples in the biobank and for their use in research experiments regarding human fertility in accordance with the 1975 Helsinki Declaration on human experimentation. The GERMETHEQUE biobank (BB-0033-00081 Marseille, France) Scientific Committee approved the present study design (number 20130102).

Straws were placed in a $37^{\circ} \mathrm{C}$ water bath for $5 \mathrm{~min}$; then, the cryoprotectant was removed by progressively diluting the thawed sample with $1 \mathrm{~mL}$ of FertiCult ${ }^{\oplus}$ culture medium at $37^{\circ} \mathrm{C}$. The prepara-

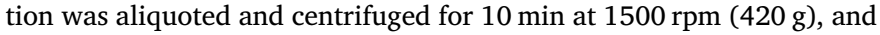

the supernatants were discarded. Then, $150 \mu \mathrm{L}$ of the subsequent suspensions were carefully disposed on each pellet. As the genotoxicity of $\mathrm{CeO}_{2} \mathrm{NP}$ on human spermatozoa had not been studied before, we assessed a wide range of $\mathrm{CeO}_{2} \mathrm{NP}$ concentrations. The suspensions used for in vitro exposure of spermatozoa were a) FertiCult ${ }^{\circledR}$ culture medium (negative control); b) FertiCult ${ }^{\circledR}$ containing $0.01,0.1,1$ or $10 \mathrm{mg} \cdot \mathrm{L}^{-1}$ $\mathrm{CeO}_{2} \mathrm{NP}$; c) the supernatant obtained after ultracentrifugation $(60,000 \mathrm{rpm}(16,000 \mathrm{~g})$ for $1 \mathrm{~h})$ of the suspensions from b); d) a $110 \mu \mathrm{M}$ $\mathrm{H}_{2} \mathrm{O}_{2}$ solution in FertiCult ${ }^{\circledR}$ (positive control); e) the same $\mathrm{CeO}_{2} \mathrm{NP}$ suspensions as described in b) with $5 \mathrm{mM}$ L-ergothioneine. LErgothioneine (L-erg) is an anti-oxidant commonly used in toxicological studies as a powerful scavenger of free radicals to explore the involvement of oxidative stress in the induction of DNA damage (Franzoni et al., 2006). We incubated the preparations for $1 \mathrm{~h}$ at $37{ }^{\circ} \mathrm{C}$ in $5 \% \mathrm{CO}_{2}$, after which we analyzed the supernatants containing motileselected spermatozoa. We therefore studied spermatozoa selected by swim-up and included all motile sperm. The in vitro culture conditions we chose corresponded to the IVF-based culture conditions, which are close to those of the female genital tract environment.

For each $\mathrm{CeO}_{2} \mathrm{NP}$ concentration, 3 different conditions were studied: 1) $\mathrm{CeO}_{2} \mathrm{NP}$ suspensions in culture medium; 2) the supernatants of the same suspensions (containing dissolved $\mathrm{Ce}^{3+}$ ); and 3) $\mathrm{CeO}_{2} \mathrm{NP}$ suspensions with $\mathrm{L}$-erg. Each condition of each concentration was repeated 3 times.

\subsection{Sperm vitality}

We assessed the viability of spermatozoa before performing each triplicate of the Comet assay to exclude sperm DNA damage associated with cytotoxicity. According to the World Health Organization manual, (World Health Organization, 2010), we combined $10 \mu \mathrm{L}$ of a $0.5 \%$ eosin solution (Gilbert ${ }^{\oplus}$, Hérouville-Saint-Clair, France) containing $0.9 \%$ $\mathrm{NaCl}$ with $10 \mu \mathrm{L}$ of the exposed sperm sample and observed the preparation at $\times 400$ under a contrast microscope. The percentage of live (unstained) and dead (red-stained) spermatozoa was assessed blindly from at least 100 evaluated cells in each condition.

\subsection{Human sperm comet assay}

The Comet assay is a common genotoxicity test that detects and quantifies DNA primary lesions of eukaryotic cells (Olive and Banáth, 2006). The Comet assay has been validated for the testing of chemicals to determine mutagenicity (Eastmond et al., 2009; Parry, 2000). It is highly sensitive, adaptable and does not require a large number of cells (Baumgartner et al., 2009). We performed a procedure adapted from Baumgartner et al. (2012), each condition and concentration in triplicates.

Each spermatozoa suspension obtained after in vitro exposure was mixed with an equal volume of $2 \%$ low melting point (LMP) agarose. The obtained suspension was spread on 3 glass slides that were precoated with $1 \%$ normal melting point (NMP) agarose. A third layer of $0.5 \%$ LMP agarose was added. Slides were immersed in a lysis buffer (100 mM EDTA, $10 \mathrm{mM}$ Tris base, $2.5 \mathrm{M} \mathrm{NaCl}, 1 \%$ Triton X-100, 10\% DMSO, $5 \mathrm{mM}$ dithiothreitol, $0.01 \mathrm{mg} \cdot \mathrm{mL}^{-1}$ proteinase $\mathrm{K}$; $\mathrm{pH} 10$ ) for $1 \mathrm{~h}$ and then transferred to an electrophoresis tank. Slides were covered by freshly prepared electrophoresis buffer ( $1 \mathrm{mM}$ EDTA, $300 \mathrm{mM} \mathrm{NaOH}$; $\mathrm{pH} 13.5$ ) at $4^{\circ} \mathrm{C}$, rested for $20 \mathrm{~min}$ for equilibration, and then electrophoresed at $25 \mathrm{~V}$ at $4{ }^{\circ} \mathrm{C}$ for $20 \mathrm{~min}$ in a $30 \mathrm{~cm}$-long electrophoresis tank. Slides were rinsed with a Tris buffer $(0.4 \mathrm{M}$ Tris base; $\mathrm{pH} 7.4)$ and dehydrated with methanol.

\subsubsection{Scoring of comet slides}

Slides were read blindly after staining with $0.1 \mathrm{mg} \cdot \mathrm{mL}^{-1}$ propidium iodide. For each condition, at least 50 spermatozoa were evaluated per slide (i.e., at least 150 spermatozoa over 3 slides per condition). All experiments were repeated three times (i.e., at least 450 spermatozoa in 
3 independent experiments per condition). Quantitative image analysis was performed using a CCD camera (Andor Technology, Belfast, UK) attached to the microscope (Olympus, Rungis, France) and linked to the comet analysis software (version 6.0; Andor Bioimaging, Nottingham, UK). Sperm DNA damage was expressed as the percentage of tail DNA (\% tail DNA), which is total DNA that migrates from the nucleus into the comet tail during electrophoresis (Baumgartner et al., 2012).

\subsection{Transmission electron microscopy (TEM)}

We performed TEM analysis on spermatozoa exposed to $0.01 \mathrm{mg} \cdot \mathrm{L}^{-1} \mathrm{CeO}_{2} \mathrm{NP}$ for $1 \mathrm{~h}$ in order to explore the interaction between $\mathrm{CeO}_{2} \mathrm{NP}$ and spermatozoa at the lowest studied concentration. Samples were washed two times in phosphate buffer, fixed with $2.5 \%$ glutaraldehyde for $30 \mathrm{~min}$, dehydrated in a graded series of ethanol and finally embedded with an Embed-812 kit using a standard procedure. Ultrathin sections of $60 \mathrm{~nm}$ were examined with a JEOL/JEM 1400 apparatus, and images were obtained with a MegaView III CCD camera (SIS-Olympus, Munster, Germany).

\subsection{Statistics}

Each experiment contained at least 150 raw values of \% tail DNA by condition and was replicated 3 times: the data for each condition are presented as the 3 means of \% Tail DNA median values form the 3 independent experiments. For each condition, we summarized the values obtained for every experiment and performed a one-way ANOVA test using StatView 5.1 software (Abacus Concept, Berkeley, CA, USA)., to compare DNA damage between the various concentration levels and control, between the various concentrations and, for each concentration, between the 3 conditions (Krzywinski et al., 2014). Differences were considered statistically significant at $\mathrm{p}<0.05$.

\section{Results}

\subsection{Colloidal and chemical behavior of $\mathrm{CeO}_{2} \mathrm{NP}$ in FertiCult ${ }^{\circledR}$ medium}

Fig. 1a shows the distribution of the hydrodynamic diameters $\left(D_{h}\right)$ of $100 \mathrm{mg} \cdot \mathrm{L}^{-1} \mathrm{CeO}_{2} \mathrm{NP}$ after a 1-h incubation in FertiCult ${ }^{\circledR}$ medium. Although $\mathrm{CeO}_{2} \mathrm{NP}$ are colloidally stable in their stock suspension (with a $\mathrm{D}_{\mathrm{h}}$ distribution centered at $\sim 7 \mathrm{~nm}$ ), significant aggregation occurred in the FertiCult ${ }^{\circledR}$ with a $D_{h}$ centered at $3.6 \mu$ m (volume distribution). Once expressed as a number, the distribution of most of these aggregates had a $D_{h}$ centered at $190 \mathrm{~nm}$. Even if this number distribution is based on assumptions regarding the shape, the density of the aggregates, etc., it highlights that most of the $\mathrm{CeO}_{2} \mathrm{NP}$ interact with the spermatozoa as small aggregates.

The chemical stability of the nanoparticles was studied in FertiCult ${ }^{\circledR}$ medium in terms of dissolution and local-scale environment. The ICPMS measurements show that $<2 \%$ and $0.02 \%$ of the $\mathrm{CeO}_{2} \mathrm{NP}$ were dissolved after $1 \mathrm{~h}$ from initial $\mathrm{CeO}_{2}$ concentrations of $0.01 \mathrm{mg} \cdot \mathrm{L}^{-1}$ and $10 \mathrm{mg} \cdot \mathrm{L}^{-1}$, respectively (Fig. 3). This is in agreement with the low solubility expected for Ce oxy-hydroxide (as $\mathrm{Ksp}_{\mathrm{Ce}(\mathrm{OH}) 3}=6.3 \times 10^{-24}$ at $25^{\circ} \mathrm{C}$ ) (Söhnel and Garside, 1992). This chemical stability was also observed by XANES at the Ce $\mathrm{L}_{3}$-edge (Fig. 1b). The experimental spectra of $\mathrm{CeO}_{2} \mathrm{NP}$ before and after the 1-h incubation in FertiCult ${ }^{\circledR}$ are superimposed and indicate that the atomic structure of $\mathrm{CeO}_{2} \mathrm{NP}$ is not affected. XANES is not sensitive to minor Ce species (i.e., $<10 \%$ ). Consequently, the detection of $<2 \%$ Ce dissolution is not contradictory with the structural stability observed by XANES. Such local-scale stability and slow dissolution suggests that the $\mathrm{CeO}_{2} \mathrm{NP}$ surface interaction with molecules in the FertiCult ${ }^{\circledR}$ medium is not associated with major surface complexation or reduction into Ce(III).

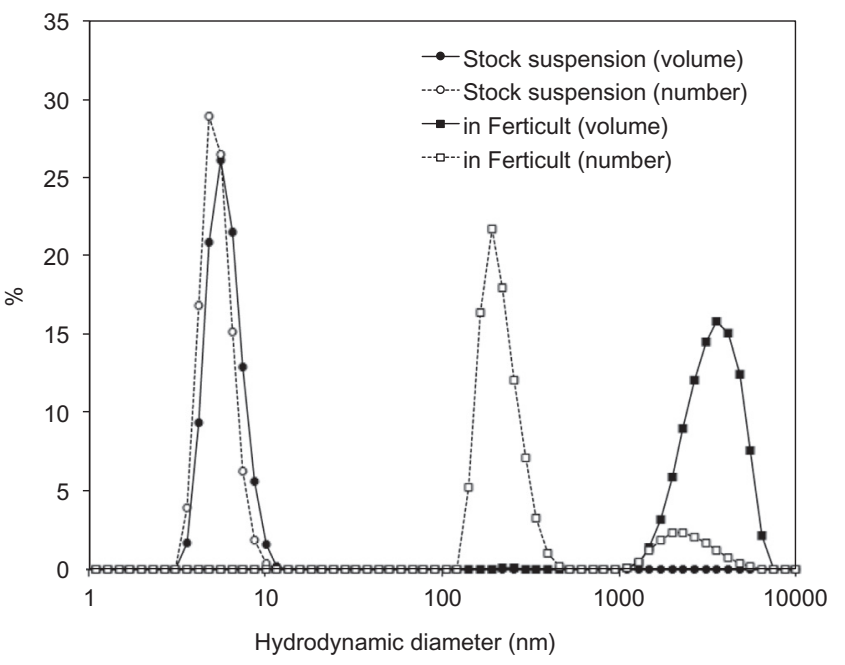

(a)

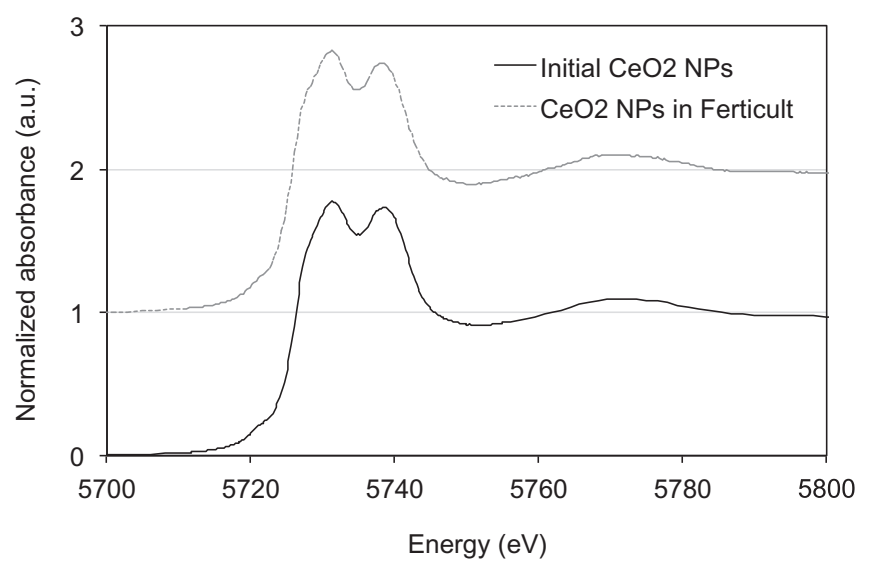

(b)

Fig. 1. Colloidal behavior of $\mathrm{CeO}_{2} \mathrm{NP}$ in abiotic culture medium. (a) Distribution of the hydrodynamic diameters of $\mathrm{CeO}_{2} \mathrm{NP}$ in their stock suspension and after $1 \mathrm{~h}$ in FertiCult ${ }^{\oplus}$ at $100 \mathrm{mg}^{-1} \mathrm{~L}^{-1} \mathrm{CeO}_{2}$. (b) Structural stability of $\mathrm{CeO}_{2} \mathrm{NP}$ after $1 \mathrm{~h}$ of incubation in $\mathrm{FertiCult}^{\circledR}$ medium as assessed by XANES at the $\mathrm{Ce}_{3}$-edge.

\subsection{Human sperm comet assay}

The spermatozoa viability rates were all $>58 \%$, which is the normality threshold for human spermatozoa as stated by the WHO criteria (World Health Organization, 2010).

DNA damage in the spermatozoa was quantified by $\%$ tail DNA. The variability of biological data in the 3 independent experiments and in each 3 replicate slide of each independant experiment is presented in Table 1.

The comet assay showed that compared to the negative control, there was a significant increase of DNA damage in human spermatozoa after in vitro exposure to $\mathrm{CeO}_{2} \mathrm{NP}$ at all concentrations (Fig. 2), the supernatants of the $\mathrm{CeO}_{2} \mathrm{NP}$ suspensions (Fig. 3) and the L-erg conditions (Fig. 2), ( $\mathrm{p}<0.0001)$.

We detected a significant increase in DNA damage in spermatozoa exposed to the lowest nanoparticle concentrations, i.e., $0.01 \mathrm{mg} \cdot \mathrm{L}^{-1}$ $\mathrm{CeO}_{2} \mathrm{NP}$ (mean median $=69.8$ ) versus higher concentrations i.e. $0.1 \mathrm{mg} \cdot \mathrm{L}^{-1}, 1$ and $10 \mathrm{mg} \cdot \mathrm{L}^{-1} \mathrm{CeO}_{2} \mathrm{NP}$ (55.0, 53.2 and 46.5, respectively) ( $\mathrm{p}<0.001)$.

We observed no significant difference among the 3 conditions $\left(\mathrm{CeO}_{2} \mathrm{NP}\right.$, supernatants and L-erg). 
Table 1

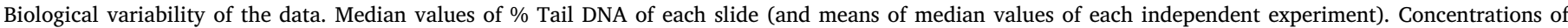

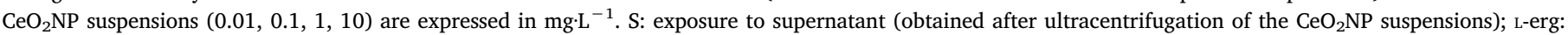
adjunction of L-ergothioneine (anti-oxidant) in the $\mathrm{CeO}_{2} \mathrm{NP}$ suspension.

\begin{tabular}{|c|c|c|c|c|c|c|c|c|c|c|c|c|c|c|c|}
\hline & & Negative control & Positive control & 0.01 & $0.01 \mathrm{~S}$ & $0.01 \mathrm{~L}$-erg & 0.1 & $0.1 \mathrm{~S}$ & 0.1 L-erg & 1 & $1 \mathrm{~S}$ & 1 L-erg & 10 & $10 \mathrm{~S}$ & 10 L-erg \\
\hline \multirow[t]{4}{*}{ Experiment 1} & Slide 1 & 36,9 & 74,5 & 73,9 & 62,3 & 49,9 & 65,1 & 62,4 & 62,5 & 52,0 & 55,0 & 54,7 & 40,0 & 48,6 & 45,2 \\
\hline & Slide 2 & 37,3 & 73,3 & 72,5 & 52,2 & 55,3 & 53,8 & 57,2 & 57,9 & 47,7 & 49,9 & 48,3 & 47,2 & 50,0 & 39,0 \\
\hline & Slide 3 & 32,5 & 75,6 & 69,4 & 65,7 & 64,2 & 53,4 & 59,7 & 58,8 & 51,6 & 59,2 & 61,0 & 52,6 & 41,4 & 42,2 \\
\hline & Mean of medians & 35,6 & 74,5 & 71,9 & 60,0 & 56,4 & 57,4 & 59,8 & 59,7 & 50,4 & 54,7 & 54,7 & 46,6 & 46,6 & 42,1 \\
\hline \multirow[t]{4}{*}{ Experiment 2} & Slide 1 & 34,7 & 74,8 & 73,1 & 68,0 & 69,6 & 56,8 & 61,5 & 68,8 & 58,7 & 57,2 & 64,6 & 49,7 & 46,3 & 53,1 \\
\hline & Slide 2 & 35,7 & 75,3 & 78,3 & 55,5 & 65,9 & 56,9 & 57,8 & 59,1 & 52,5 & 64,7 & 59,2 & 51,1 & 34,1 & 41,8 \\
\hline & Slide 3 & 32,0 & 68,3 & 69,8 & 65,7 & 63,0 & 53,9 & 63,3 & 67,1 & 52,0 & 56,6 & 61,1 & 48,5 & 49,0 & 47,6 \\
\hline & Mean of medians & 34,1 & 72,8 & 73,7 & 63,0 & 66,2 & 55,9 & 60,9 & 65,0 & 54,4 & 59,5 & 61,7 & 49,8 & 43,1 & 47,5 \\
\hline \multirow[t]{4}{*}{ Experiment 3} & Slide 1 & 32,6 & 69,2 & 62,7 & 52,7 & 58,2 & 57,6 & 62,5 & 64,2 & 48,6 & 53,9 & 39,4 & 41,0 & 44,6 & 39,0 \\
\hline & Slide 2 & 34,0 & 65,9 & 61,5 & 61,2 & 65,1 & 45,6 & 57,8 & 67,1 & 58,1 & 55,4 & 60,5 & 46,8 & 54,0 & 42,3 \\
\hline & Slide 3 & 39,8 & 63,7 & 66,7 & 60,9 & 61,5 & 51,8 & 50,9 & 60,1 & 57,4 & 56,1 & 68,9 & 41,5 & 36,6 & 49,6 \\
\hline & Mean of medians & 35,4 & 66,3 & 63,6 & 58,2 & 61,6 & 51,7 & 57,1 & 63,8 & 54,7 & 55,1 & 56,3 & 43,1 & 45,1 & 43,6 \\
\hline
\end{tabular}

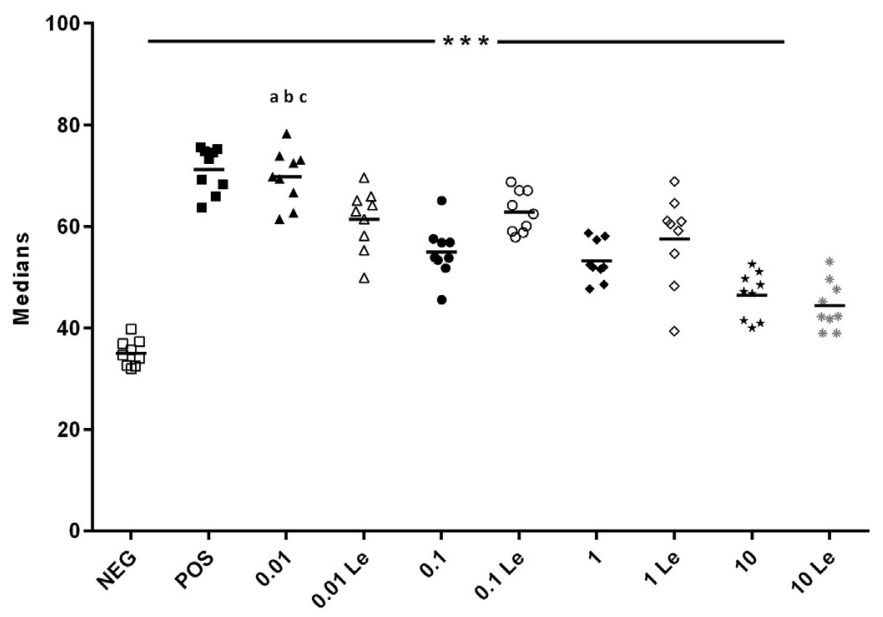

Fig. 2. The comet assay shows, compared to the negative control, a significant increase of DNA damage in human sperm after a 1-hour in vitro exposure to $\mathrm{CeO}_{2} \mathrm{NP}$ at all concentrations as well as in the presence of an anti-oxidant, L-erg $\left.{ }^{*}\right)(\mathrm{p}<0.0001)$. The results are presented as the 9 median values of $\%$ Tail DNA obtained from 9 different slides from 3 independent experiments for each condition. L-erg: L-ergothioneine (anti-oxidant). a: $v s .0 .1 \mathrm{mg} \cdot \mathrm{L}^{-1} \mathrm{CeO}_{2} \mathrm{NP}$. b: $v$. $1 \mathrm{mg} \cdot \mathrm{L}^{-1} \mathrm{CeO}_{2} \mathrm{NP}$. c: vs. $10 \mathrm{mg} \cdot \mathrm{L}^{-1} \mathrm{CeO}_{2} \mathrm{NP}$ ( $\mathrm{p}<0.0001$ ). Positive control: $110 \mu \mathrm{M} \mathrm{H}_{2} \mathrm{O}_{2}$.

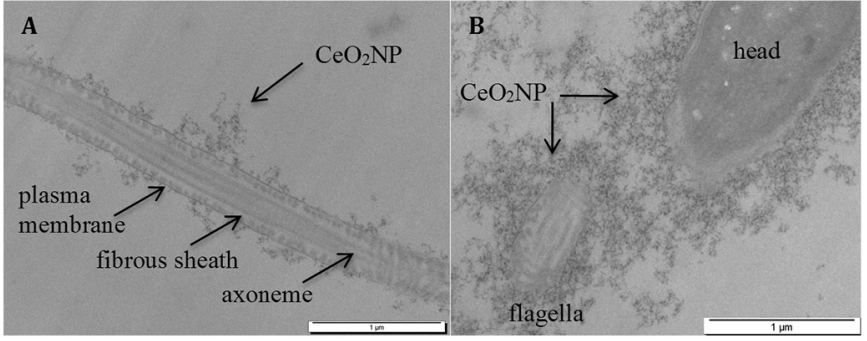

Fig. 4. The TEM aspect of human spermatozoa exposed to $0.01 \mathrm{mg} \cdot \mathrm{L}^{-1} \mathrm{CeO}_{2} \mathrm{NP}$ in vitro. One-hour exposure at $0.01 \mathrm{mg} \cdot \mathrm{L}^{-1}$ : accumulation of nanoparticles $(\rightarrow)$ on the plasma membrane. A) Longitudinal section of the flagella. B) Transversal section of the flagella (on the left) and head.

\subsection{TEM analysis of spermatozoa}

After a $1 \mathrm{~h}$ incubation in $0.01 \mathrm{mg} \cdot \mathrm{L}^{-1} \mathrm{CeO}_{2} \mathrm{NP}$ suspension in FertiCult ${ }^{\circledast}$ culture medium, TEM showed the accumulation of $\mathrm{CeO}_{2} \mathrm{NP}$ on the plasma membranes of exposed human spermatozoa (Fig. 4), particularly along the flagellum. We did not observe any internalization of $\mathrm{CeO}_{2} \mathrm{NP}$ in spermatozoa.

\section{Discussion}

We showed that in vitro exposure of human spermatozoa to $\mathrm{CeO}_{2} \mathrm{NP}$ significantly increased DNA damage at all concentrations as assessed by

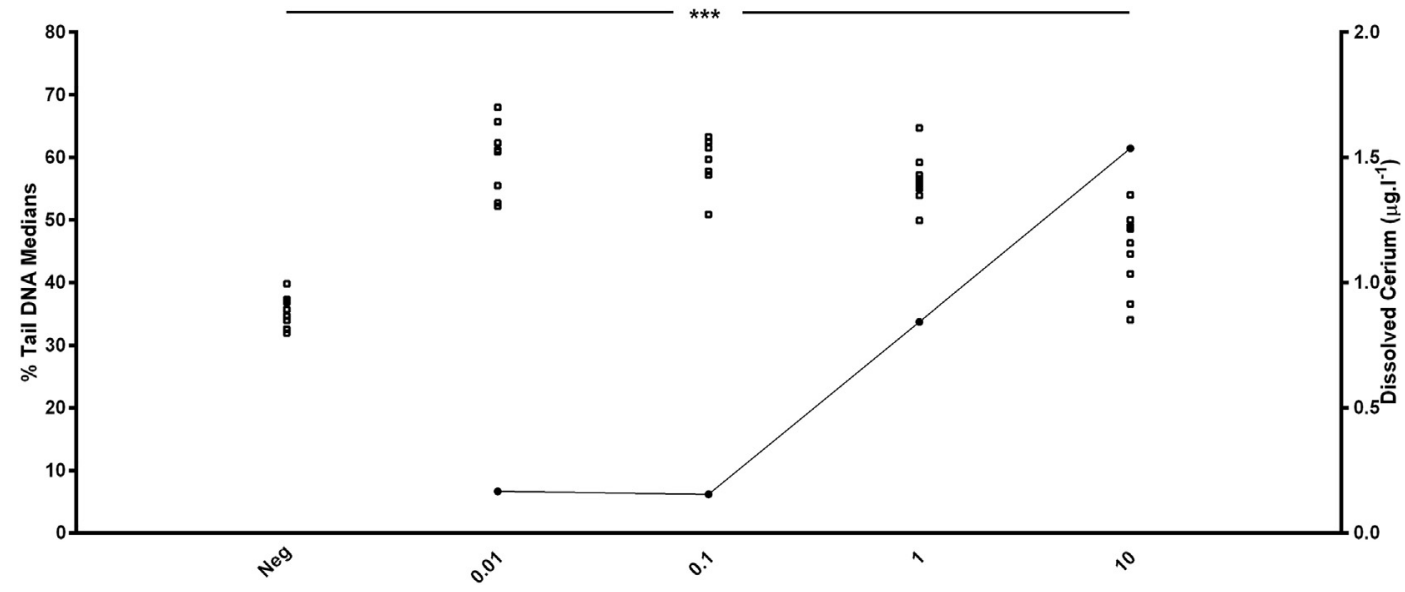

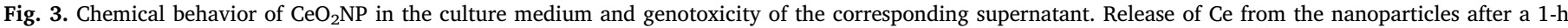

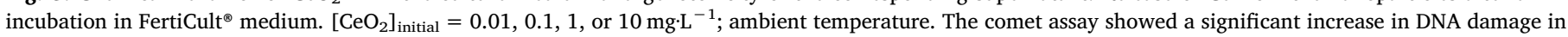

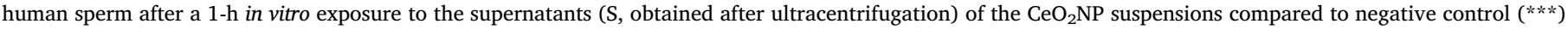

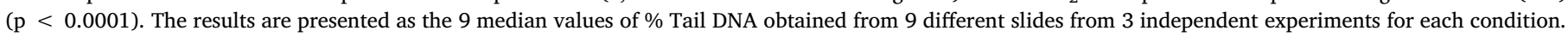


the comet assay. We did not observe any internalization of $\mathrm{CeO}_{2} \mathrm{NP}$ in spermatozoa. Interestingly, the lowest concentrations of nanoparticles were associated with the highest amount of DNA damage.

A strong point of our study design is the wide range of $\mathrm{CeO}_{2} \mathrm{NP}$ concentrations explored, including very low concentrations $(0.01$ to $10 \mathrm{mg} \cdot \mathrm{L}^{-1}$ ). Indeed, the majority of recent studies about the genotoxicity of $\mathrm{CeO}_{2} \mathrm{NP}$ on human cells analyzed the impact of nanoparticle concentrations ranging from 0.1 to $100 \mathrm{mg} \cdot \mathrm{L}^{-1}$ (Franchi et al., 2015; Mittal and Pandey, 2014; Strobel et al., 2015; Verstraelen et al., 2014; Yoisungnern et al., 2015). We addressed lower exposure doses that are probably closer to the expected in vivo concentrations and remain poorly investigated. Nevertheless, to the best of our knowledge, no information is available about the expected human in vivo concentrations in the testes, seminal ducts, uterus or Fallopian tubes. Another strong point is that we performed an extensive chemical and physical characterization of the nanoparticles; this type of data are essential for toxicity studies in vitro and in vivo (Love et al., 2012).

The inverse dose-effect relationship observed has been described in previous nanotoxicity studies. Sergent et al. studied the toxicity of $100 \mathrm{~nm} \mathrm{SiO}{ }_{2}$ nanoparticles (concentrations ranging from 10 to $150 \mathrm{mg} \cdot \mathrm{L}^{-1}$ ) on the HT-29 human intestine cell line and showed inverse dose-dependent relationships between the nanoparticle concentration and cell viability and genotoxicity (Sergent et al., 2012). The authors hypothesized that the phenomenon of phagocytosis of damaged cells by undamaged cells could occur to maintain the integrity of the islet profile. Since sperm have no phagocytic abilities, it is unlikely that such a mechanism was involved in our study. Our results could be explained by dose-dependent changes in the physico-chemical behavior. At low doses, the probability of contact between two particles (homoaggregation) decreases, and it is likely that $\mathrm{CeO}_{2} \mathrm{NP}$ are more dispersed at lower concentrations. Indeed, agglomeration increases the contact surface between NP. Consequently, CeO2NP dispersion could lead to small aggregates with a large surface area available to interact with cells, which could enhance the biotransformation, biological and toxicological effects (Nel et al., 2009; Yoshida et al., 2012). Future work should include genotoxicity assessments at lower concentrations.

This inverse dose response could also be related to different genotoxicity mechanisms. At the lowest concentration $\left(0.01 \mathrm{mg} \cdot \mathrm{L}^{-1}\right)$, the adjunction of an anti-oxidant (L-erg) in the exposure medium decreased DNA damage in the sperm. This indirectly highlights that oxidative stress is one mechanism involved in the observed DNA damage. With their high redox potential, $\mathrm{CeO}_{2} \mathrm{NP}$ can easily become reduced once in close contact with spermatozoa, thereby oxidizing the nearby organic molecules (Auffan et al., 2009a; Xu and Qu, 2014). Oxidative stress induced by in vitro exposure to $\mathrm{CeO}_{2} \mathrm{NP}$ has been described in human lung cells (leading to cytotoxicity (Mittal and Pandey, 2014)) and dermal fibroblasts (leading to DNA and chromosome damages (Auffan et al., 2009b)). Oxidative stress is known to induce DNA damage in sperm by oxidizing DNA bases (Aitken and Iuliis, 2010). A higher oxidative stress at very low concentration could be related to a higher contact surface between sperm and $\mathrm{CeO} 2 \mathrm{NP}$, which could enhance the toxicological effect (Nel et al., 2009; Yoshida et al., 2012). These results are in agreement with previous nanotoxicity studies performed on mouse gametes (Greco et al., 2015b; Preaubert et al., 2015) and corroborate a mechanism of DNA damage occurring at low concentrations of nanoparticles $\left(0.01 \mathrm{mg} \cdot \mathrm{L}^{-1}\right)$, thus requiring a close interaction between the cells and the $\mathrm{CeO}_{2} \mathrm{NP}$.

At higher concentrations $\left(0.1,1\right.$ and $\left.10 \mathrm{mg} \cdot \mathrm{L}^{-1}\right)$, no difference was observed between the applied nanoparticles and DNA damage induced among the 3 experimental conditions (exposure to $\mathrm{CeO}_{2} \mathrm{NP}$ suspension, supernatant or $\mathrm{CeO}_{2} \mathrm{NP}$ suspension + anti-oxidant), suggesting that the genotoxicity mechanisms are different and that oxidative stress is not involved. At all studied concentrations, the dissolved cerium concentration in the supernatant did not increase proportionally to the nanoparticles concentration: for example, whereas the concentration of nanoparticles increased 1000-fold, the dissolved cerium increased only 8-fold (Fig. 3). We assume that at all concentrations, dissolved cerium could be involved in the observed genotoxicity. Indeed, the $\mathrm{Ce}^{3+}$ ions present in the nanoparticle stock suspension related to cerium dissolution in the culture medium could diffuse through the plasma membrane and indirectly stress the spermatozoa. Our results confirm the importance of a careful assessment of the physico-chemical behavior of nanoparticles to better understand the mechanisms of genotoxicity towards germ cells.

Our study is limited by its in vitro nature. However, these results of in vitro exposure are interesting, as spermatozoa can encounter nanoparticles in the female genital tract or in IVF plots. Indeed, metal nanoparticles can transfer to various organs in animals after in vivo exposure (Blum et al., 2012; Gao et al., 2012; Tassinari et al., 2014), and nanomaterials have been increasingly studied as future medical applications (Barkalina et al., 2014).

In mice, we previously found that in vitro exposure to $\mathrm{CeO}_{2} \mathrm{NP}$ was associated with decreased fertilization rates (Preaubert et al., 2015). DNA damage in spermatozoa could be partly responsible for the decreased fertilization rates. The present results show that very low concentrations of $\mathrm{CeO}_{2} \mathrm{NP}$ also induce DNA damage in human sperm. For obvious ethical reasons, the impact of $\mathrm{CeO}_{2} \mathrm{NP}$ on human in vitro fertilization could not be analyzed.

\section{Conclusion}

This study shows for the first time that in vitro exposure to very low concentrations of cerium dioxide nanoparticles induces significant DNA damage in human spermatozoa. These results add new and important insights regarding the reproductive toxicity of priority nanomaterials requiring urgent evaluation and warrant further in vivo animal studies examining exposure to low concentrations of $\mathrm{CeO}_{2} \mathrm{NP}$.

\section{Acknowledgements}

This work was supported by the LABEX SERENADE (No. ANR-11LABX-0064) and has been completed with the support of the A*MIDEX project " CREER » (No. ANR-11-IDEX-0001-02) funded by the " Investissements d'Avenir », French Government Program of the French National Research Agency (ANR) through the A*MIDEX project (No. ANR-11-IDEX-0001-02).

We are particularly grateful to Bernard Angeletti for his technical help to achieve this project, Joël Courageot for his expert preparation and analysis of TEM samples, and GERMETHEQUE biobank (BB-003300081 Marseille, France).

\section{Conflict of interest}

The authors report no conflicts of interest.

\section{References}

Aitken, R.J., Iuliis, G.N.D., 2010. On the possible origins of DNA damage in human spermatozoa. Mol. Hum. Reprod. 16, 3-13.

Auffan, M., Rose, J., Wiesner, M.R., Bottero, J.Y., 2009a. Chemical stability of metallic nanoparticles: a parameter controlling their potential cellular toxicity in vitro. Environ. Pollut. Barking Essex 1987 (157), 1127-1133.

Auffan, M., Rose, J., Orsiere, T., Meo, M.D., Thill, A., Zeyons, O., Proux, O., Masion, A. Chaurand, P., Spalla, O., Botta, A., Wiesner, M.R., Bottero, J.Y., 2009b. $\mathrm{CeO}_{2}$ nanoparticles induce DNA damage towards human dermal fibroblasts in vitro. Nanotoxicology 3, 161-171.

Barkalina, N., Charalambous, C., Jones, C., Coward, K., 2014. Nanotechnology in reproductive medicine: emerging applications of nanomaterials. Nanomed. Nanotechnol. Biol. Med. 10, 921-938.

Baumgartner, A., Cemeli, E., Anderson, D., 2009. The comet assay in male reproductive toxicology. Cell Biol. Toxicol. 25, 81-98.

Baumgartner, A., Kurzawa-Zegota, M., Laubenthal, J., Cemeli, E., Anderson, D., 2012. Comet-assay parameters as rapid biomarkers of exposure to dietary/environmental compounds - an in vitro feasibility study on spermatozoa and lymphocytes. Mutat. Res. Toxicol. Environ. Mutagen. 743, 25-35.

Benameur, L., Auffan, M., Cassien, M., Liu, W., Culcasi, M., Rahmouni, H., Stocker, P., 
Tassistro, V., Bottero, J.-Y., Rose, J., Botta, A., Pietri, S., 2015. DNA damage and oxidative stress induced by $\mathrm{CeO}_{2}$ nanoparticles in human dermal fibroblasts: evidence of a clastogenic effect as a mechanism of genotoxicity. Nanotoxicology 9, 696-705.

Blum, J.L., Xiong, J.Q., Hoffman, C., Zelikoff, J.T., 2012. Cadmium associated with inhaled cadmium oxide nanoparticles impacts fetal and neonatal development and growth. Toxicol. Sci. Off. J. Soc. Toxicol. 126, 478-486.

Cassee, F.R., van Balen, E.C., Singh, C., Green, D., Muijser, H., Weinstein, J., Dreher, K., 2011. Exposure, health and ecological effects review of engineered nanoscale cerium and cerium oxide associated with its use as a fuel additive. Crit. Rev. Toxicol. 41, 213-229.

Courbiere, B., Auffan, M., Rollais, R., Tassistro, V., Bonnefoy, A., Botta, A., Rose, J., Orsière, T., Perrin, J., 2013. Ultrastructural interactions and genotoxicity assay of cerium dioxide nanoparticles on mouse oocytes. Int. J. Mol. Sci. 14, 21613-21628.

Eastmond, D.A., Hartwig, A., Anderson, D., Anwar, W.A., Cimino, M.C., Dobrev, I., Douglas, G.R., Nohmi, T., Phillips, D.H., Vickers, C., 2009. Mutagenicity testing for chemical risk assessment: update of the WHO/IPCS harmonized scheme. Mutagenesis 24, 341-349.

Ema, M., Kobayashi, N., Naya, M., Hanai, S., Nakanishi, J., 2010. Reproductive and developmental toxicity studies of manufactured nanomaterials. Reprod. Toxicol. 30, 343-352.

Falchi, L., Bogliolo, L., Galleri, G., Ariu, F., Zedda, M.T., Pinna, A., Malfatti, L., Innocenzi, P., Ledda, S., 2016. Cerium dioxide nanoparticles did not alter the functional and morphologic characteristics of ram sperm during short-term exposure. Theriogenology 85, 1274-1281.e3.

Franchi, L.P., Manshian, B.B., de Souza, T.A.J., Soenen, S.J., Matsubara, E.Y., Rosolen, J.M., Takahashi, C.S., 2015. Cyto- and genotoxic effects of metallic nanoparticles in untransformed human fibroblast. Toxicol. in Vitro 29, 1319-1331.

Franzoni, F., Colognato, R., Galetta, F., Laurenza, I., Barsotti, M., Di Stefano, R., Bocchetti, R., Regoli, F., Carpi, A., Balbarini, A., Migliore, L., Santoro, G., 2006. An in vitro study on the free radical scavenging capacity of ergothioneine: comparison with reduced glutathione, uric acid and trolox. Biomed. Pharmacother. 60, 453-457 International Congress, Pisa, October 10-13, 2006.

Gao, G., Ze, Y., Li, B., Zhao, X., Zhang, T., Sheng, L., Hu, R., Gui, S., Sang, X., Sun, Q., Cheng, J., Cheng, Z., Wang, L., Tang, M., Hong, F., 2012 Ovarian dysfunction and gene-expressed characteristics of female mice caused by long-term exposure to titanium dioxide nanoparticles. J. Hazard. Mater. 243, 19-27.

Geraets, L., Oomen, A.G., Schroeter, J.D., Coleman, V.A., Cassee, F.R., 2012. Tissue distribution of inhaled micro- and nano-sized cerium oxide particles in rats: results from a 28-day exposure study. Toxicol. Sci. 127, 463-473.

Giri, S., Karakoti, A., Graham, R.P., Maguire, J.L., Reilly, C.M., Seal, S., Rattan, R. Shridhar, V., 2013. Nanoceria: a rare-earth nanoparticle as a novel anti-angiogenic therapeutic agent in ovarian cancer. PLoS One 8, e54578.

Greco, F., Courbière, B., Rose, J., Orsière, T., Sari-Minodier, I., Bottero, J.-Y., Auffan, M., Perrin, J., 2015a. Toxicity of nanoparticles on reproduction. Gynécologie Obstétrique Fertil. 43, 49-55.

Greco, F., Perrin, J., Auffan, M., Tassistro, V., Orsière, T., Courbiere, B., 2015b. A new approach for the oocyte genotoxicity assay: adaptation of comet assay on mouse cumulus-oocyte complexes. Lab. Anim. 49, 251-254.

Kobyliak, N.M., Falalyeyeva, T.M., Kuryk, O.G., Beregova, T.V., Bodnar, P.M., Zholobak, N.M., Shcherbakov, O.B., Bubnov, R.V., Spivak, M.Y., 2015. Antioxidative effects of cerium dioxide nanoparticles ameliorate age-related male infertility: optimistic results in rats and the review of clinical clues for integrative concept of men health and fertility. EPMA J. 6, 12.

Krzywinski, M., Altman, N., Blainey, P., 2014. Points of significance: nested designs. For studies with hierarchical noise sources, use a nested analysis of variance approach. Nat. Methods 11 (10), 977-978.

Love, S.A., Maurer-Jones, M.A., Thompson, J.W., Lin, Y.S., Haynes, C.L., 2012. Assessing nanoparticle toxicity. Annu. Rev. Anal. Chem. Palo Alto Calif. 5, 181-205.

Lovell, D.P., Omori, T., 2008. Statistical issues in the use of the comet assay. Mutagenesis 23 (3), 171-182.

Mittal, S., Pandey, A.K., 2014. Cerium oxide nanoparticles induced toxicity in human lung cells: role of ROS mediated DNA damage and apoptosis. Biomed. Res. Int. 2014, 891934.

Moretti, E., Terzuoli, G., Renieri, T., Iacoponi, F., Castellini, C., Giordano, C., Collodel, G., 2013. In vitro effect of gold and silver nanoparticles on human spermatozoa.
Andrologia 45, 392-396.

Nel, A.E., Mädler, L., Velegol, D., Xia, T., Hoek, E.M.V., Somasundaran, P., Klaessig, F., Castranova, V., Thompson, M., 2009. Understanding biophysicochemical interactions at the nano-bio interface. Nat. Mater. (7), 543-557.

OECD's Guidelines, 2011. OECD's Meeting on Safety Testing of Manufactured

Nanomaterials and Test Guidelines. March 2011, available on. http://www.oecd.org.

OECD's Guidelines, 2014. Guideline for the Testing of Chemicals by In Vivo Mammalian Comet Assay. November 2017, available on. http://www.oecd.org.

Olive, P.L., Banáth, J.P., 2006. The comet assay: a method to measure DNA damage in individual cells. Nat. Protoc. 1, 23-29.

Park, B., Donaldson, K., Duffin, R., Tran, L., Kelly, F., Mudway, I., Morin, J.-P., Guest, R., Jenkinson, P., Samaras, Z., Giannouli, M., Kouridis, H., Martin, P., 2008. Hazard and risk assessment of a nanoparticulate cerium oxide-based diesel fuel additive - a case study. Inhal. Toxicol. 20, 547-566.

Parry, J.M., Parry, J., 2000. Guidance on a strategy for testing of chemicals for mutagenicity. In: Committee on Mutagenicity of chemicals in Food, Consumer Products and the Environment, available on internet. http://www.cometassayindia.org/COM $\% 20$ GUIDELINES.pdf.

Preaubert, L., Courbiere, B., Achard, V., Tassistro, V., Greco, F., Orsiere, T., Bottero, J.Y., Rose, J., Auffan, M., Perrin, J., 2015. Cerium dioxide nanoparticles affect in vitro fertilization in mice. Nanotoxicology 10, 111-117.

Sack, M., Alili, L., Karaman, E., Das, S., Gupta, A., Seal, S., Brenneisen, P., 2014. Combination of conventional chemotherapeutics with redox-active cerium oxide nanoparticles - a novel aspect in cancer therapy. Mol. Cancer Ther. 13, 1740-1749.

Sergent, J.A., Paget, V., Chevillard, S., 2012. Toxicity and genotoxicity of Nano-SiO2 on human epithelial intestinal HT-29 cell line. Ann. Occup. Hyg. 56, 622-630.

Söhnel, O., Garside, J., 1992. Precipitation. In: Butterworth-Heinemann (Ed.), Basic Principles and Industrial Applications. Boston, pp. 149.

Spalla, O., Cabane, B., 1993. Growth of colloidal aggregates through polymer bridging. Colloid Polym. Sci. 271, 357-371.

Strobel, C., Oehring, H., Herrmann, R., Förster, M., Reller, A., Hilger, I., 2015. Fate of cerium dioxide nanoparticles in endothelial cells: exocytosis. J. Nanopart. Res. 17, $1-14$.

Tarnuzzer, R.W., Colon, J., Patil, S., Seal, S., 2005. Vacancy engineered ceria nanostructures for protection from radiation-induced cellular damage. Nano Lett. 5 , 2573-2577.

Tassinari, R., Cubadda, F., Moracci, G., Aureli, F., D'Amato, M., Valeri, M., De Berardis, B., Raggi, A., Mantovani, A., Passeri, D., Rossi, M., Maranghi, F., 2014. Oral, short-term exposure to titanium dioxide nanoparticles in Sprague-Dawley rat: focus on reproductive and endocrine systems and spleen. Nanotoxicology 8, 654-662.

Taylor, U., Tiedemann, D., Rehbock, C., Kues, W.A., Barcikowski, S., Rath, D., 2015. Influence of gold, silver and gold-silver alloy nanoparticles on germ cell function and embryo development. Beilstein J. Nanotechnol. 6, 651-664.

Thill, A., Zeyons, O., Spalla, O, Chauvat, F, Rose, J., Auffan, M., et al, 2006. Cytotoxicity of $\mathrm{CeO}_{2}$ nanoparticles for Escherichia coli. Physico-chemical insight of the cytotoxicity mechanism. Environ. Sci. Technol. 40, 6151-6156.

Verstraelen, S., Remy, S., Casals, E., De Boever, P., Witters, H., Gatti, A., Puntes, V. Nelissen, I., 2014. Gene expression profiles reveal distinct immunological responses of cobalt and cerium dioxide nanoparticles in two in vitro lung epithelial cell models. Toxicol. Lett. 228, 157-169.

Wiklund, S.J., Agurell, E., 2003. Aspects of design and statistical analysis in the comet assay. Mutagenesis 18, 167-175.

World Health Organization, 2010. WHO Laboratory Manual for the Examination and Processing of Human Semen, Fifth Edition, Available on the Internet.

Xu, C., Qu, X., 2014. Cerium oxide nanoparticle: a remarkably versatile rare earth nanomaterial for biological applications. NPG Asia Mater. 6, e90.

Yoisungnern, T., Choi, Y.J., Woong Han, J., Kang, M.-H., Das, J., Gurunathan, S., Kwon, D.-N., Cho, S.-G., Park, C., Kyung Chang, W., Chang, B.-S., Parnpai, R., Kim, J.-H., 2015. Internalization of silver nanoparticles into mouse spermatozoa results in poor fertilization and compromised embryo development. Sci. Rep. 5, 11170.

Yoshida, T., Yoshioka, Y., Matsuyama, K., Nakazato, Y., Tochigi, S., Hirai, T., Kondoh, S., Nagano, K., Abe, Y., Kamada, H., Tsunoda, S.I., Nabeshi, H., Yoshikawa, T., Tsutsumi, Y., 2012. Surface modification of amorphous nanosilica particles suppresses nanosilica-induced cytotoxicity, ROS generation, and DNA damage in various mammalian cells. Biochem. Biophys. Res. Commun. 427, 748-752. 